\title{
EXOGENOUS PLANKTON AS FOOD FOR INTENSIVE REARING OF ORNAMENTAL CYPRINID, EPALZEORHYNCHUS FRENATUS
}

\author{
PLANCTON EXÓGENO COMO ALIMENTO PARA LA CRÍA INTENSIVA DEL CIPRÍNIDO \\ ORNAMENTAL EPALZEORHYNCHUS FRENATUS
}

\begin{abstract}
Jha, P. ${ }^{1,2}$
${ }^{1}$ Department of Zoology. University of North Bengal. Siliguri 734 013. District Darjeeling. West Bengal. India. ${ }^{2}$ Department of Zoology. Raiganj Surendranath Mahavidyalaya. Sudarsanpur. Raiganj 733134. West Bengal. India. jhakingshuk@rediffmail.com
\end{abstract}

\section{Additional KEYWORDS}

Rainbow shark. Diet regimen. Growth. Marketable fish. Water quality. Stocking density.

\section{SUMMARY}

To explore the effect of different management regimes for probable intensification of rainbow shark (Epalzeorhynchus frenatus) culture, fish larvae $(0.18 \pm 0.014 \mathrm{~g})$ were stocked in concrete tanks and cultured for three months (18 February18 May, 2007) according to six treatment regimes: three live food regimes where fish were stocked at $0.3 \mathrm{fish} / \mathrm{l}$ (LF1); $0.5 \mathrm{fish} / \mathrm{l}$ (LF2); and $1.0 \mathrm{fish} / \mathrm{l}$ (LF3); and three traditional (pelleted) diet regimes where fish were stocked at $0.3 \mathrm{fish} / \mathrm{l}$ (TD1); 0.5 fish/l (TD2); and 1.0 fish/l (TD3). Exogenous plankton were introduced in the live food tanks. There were three replicates for each treatment, where the fish were fed daily slightly in excess of satiation to eliminate the possibility of food supply being a limiting factor to growth. Values of dissolved oxygen were highest in LF1 treatment, followed by LF2, TD1, LF3, TD2 and TD3 ( $p<0.05)$. Average bicarbonate alkalinity, phosphate, nitrate, nitrite, and ammonium nitrogen were significantly higher $(p<0.05)$ in TD2 and TD3, compared to other treatments. Under any particular diet regime, maximum harvest weight and survival rate of rainbow shark was achieved in the treatments with lowest stocking densities (LF1 and TD1), compared to treatments with higher stocking densities $(p<0.05)$. Fish deformities were significantly higher in LF3 and TD3 $(p<0.05)$, compared with treatments with low stocking densities. At any given stocking density, the live food treatment showed better growth and survival,

\section{Palabras clave adicionales}

Tiburón arco iris. Dieta. Crecimiento. Peces comerciales. Calidad del agua. Densidad de población.

compared to traditional diet treatment. The number of marketable fish above a set size of $4 \mathrm{~g}$ was significantly higher $(p<0.05)$ in LF3 (stocking density of 1.0 fish/l), compared to other treatments. In the traditional diet tanks, increase in stocking density resulted in production loss as very few $(17.97 \%$ in TD2) or none $(0 \%$ in TD3) of the fish produced in these treatments could be marketed. Introduction of exogenous plankton as food allowed for increased stocking density for intensive rearing of rainbow shark.

\section{RESUMEN}

Para explorar la utilidad de diferentes regímenes de manejo para intensificar la cría del ciprínido Epalzeorhynchus frenatus, larvas del pez $(0,18 \pm$ $0,014 \mathrm{~g}$ ) fueron cultivadas durante tres meses (18 febrero-18 mayo 2007) en tanques de hormigón, de acuerdo con seis tratamientos: tres regímenes con alimento vivo en los que los peces se mantuvieron a una densidad de 0,3 (LF1); 0,5 (LF2); y 1,0 pez/l (LF3); y otros tres regímenes con alimentación tradicional (granulada) en los que los peces se mantuvieron a una densidad de 0,3 (TD1); 0,5 (TD2); 1,0 pez/l (TD3). Se introdujo plancton exógeno en los tanques con alimento vivo. Se hicieron tres repeticiones por tratamiento en las que los peces fueron alimentados cada día ligeramente en exceso del nivel de saciedad, para eliminar la posibilidad de que el suministro de 
alimento fuera un factor limitante del crecimiento. Los valores del oxígeno disuelto fueron más altos en el tratamiento LF1, seguido por LF2, TD1, LF3, TD2 y TD3 $(p<0,05)$. La alcalinidad bicarbonatada promedio, fosfato, nitrato, nitrito y nitrógeno amoniacal fueron más elevados $(p<0,05)$ en TD2 y TD3 que en los demás tratamientos. En cualquiera de los regímenes dietéticos las mayores tasas de ganancia de peso y de supervivencia se registraron en la densidad menor (LF1 y TD1). Las deformidades en los peces fueron significativamente más numerosas en las densidades más altas LF3 y TD3 $(p<0,05)$. A una determinada densidad, el alimento vivo produjo mejor crecimiento y supervivencia que la dieta granulada. El número de peces comercializables a un tamaño de $4 \mathrm{~g}$ fue significativamente mayor $(p<0,05)$ en LF3 $(1,0$ pez/l). En los tanques con la dieta tradicional, el aumento de la densidad dio lugar a una pérdida de producción: muy pocos $(17,97 \%$ en TD2) o ninguno $(0 \%$ en TD3) de los peces producidos en esos tratamientos pudo ser comercializado. La introducción de plancton exógeno como alimento permitió el aumento de la densidad para la cría intensiva de $E$. frenatus.

\section{INTRODUCTION}

A gradual evolution towards intensive systems for food fish production has been observed in countries having large scale operations and adopted according to local conditions (Pillay, 1993). This involves higher stocking densities, hatchery production of seed where feasible, greater human control of environmental conditions, at least supplementary feeding and higher yields per unit area (Pillay, 1993). Knowing the optimal stocking density is one of the basic factors influencing intensive fish culture. Fish stocking density is the most sensitive factor determining the productivity of a culture system as it effects growth rate, size variation and mortality (Kaiser et al., 1997). In comparison to food fish, the densities at which ornamental fishes have been kept are rather low. Among literatures available, the values range from less then 0.3 fish/ 1 for the guppy, Poecilia reticulata cultured in outdoor tanks and fed with different types of live and formulated diets (Fernando and Phang, 1985) and 0.4 fish/1 in angelfish, Pterophyllum scalare cultured in indoor tanks and fed with a commercial trout diet containing $45 \%$ protein (Degani, 1993) to 0.5 fish/1 for the gourami, Trichogaster trichopterus stocked in outdoor tanks and fed with formulated diet (Cole et al., 1997). The koi carp, Cyprinus carpio are cultured at a density of $0.25 \mathrm{fish} / \mathrm{l}$ in Hawaii (reported in Asano et al., 2003) and 0.3 fish/l in India in outdoor tanks and ponds fed with either pelleted diet or live plankton (Jha and Barat, 2005a; Jha and Barat, 2005b; Jha et al., 2006a; Jha et al., 2007). The goldfish, Carassius auratus has also been cultured at a density of 0.3 fish/l in outdoor ponds and fed with live plankton (Jha et al., 2006b).

In South Africa, there have been attempts to intensify ornamental fish production by introducing closed recirculating systems in horticultural tunnels with high water exchange rates and the authors have been successful in culturing the swordtail, Xiphophorus helleri (Olivier and Kaiser, 1997) and guppy (Kaiser et al., 1998) at a high density of 3.0 fish/l. Asano et al. (2003) was successful in culturing koi carp in Hawaii at 1.55 fish/l in outdoor greenwater tanks by using a trickle biofilter system. Since most farmers in India cannot afford high cost recirculating systems or aeration, manual water exchange in production tanks has been the only viable alternative to intensify production in ornamental fish culture units (Jha et al., 2004; Jha and Barat, $2005 \mathrm{c}$ ). Even this has limits since, in large units, it may not be possible to manually exchange more that $10 \%$ of standing water volume from the tanks every day. Introduction of exogenous plankton has been investigated as a successful alternate to traditional management systems (application of pelleted food or direct manuring) for increasing yields of ornamental cyprinid stocked at a density of 0.3 fish/l (Jha and Barat, 2005b; Jha et al., 2006a; Jha et al., 2007). Since an optimal water quality can be maintained in production

Archivos de zootecnia vol. 59, núm. 225, p. 12. 
systems supplied with exogenous plankton, it could arguably permit a higher stocking density.

The rainbow shark, Epalzeorhynchus frenatus is a popular ornamental fish throughout the world. Barring a preliminary investigation on the use of artificial feed to raise rainbow shark larvae (McGovernHopkins et al., 2002), growth of the fish under husbandry conditions has not been well documented. The objective of the present study was to investigate the effect of introduction of exogenous plankton on the growth, survival and number of marketable rainbow shark stocked at different densities and compare the results with fish given a traditional pelleted diet.

\section{MATERIALSAND METHODS}

The experiment was conducted in eighteen concrete tanks $(2.13 \times 0.91 \times 1.22 \mathrm{~m}$; capacity: 2000 l each) in Raninagar village of Jalpaiguri district, India. In nine of these tanks (live food or LF tanks), exogenous plankton was introduced as food, where as in the other nine (traditional diet or TD tanks), a commercial, floating pelleted diet (Tokyu company, Japan) containing 32\% crude protein, $4 \%$ crude fat, $5 \%$ crude fiber, $10 \%$ crude ash, $9 \%$ moisture, and $31 \%$ nitrogen-free extract was given as food. No pelleted diet was applied to the LF tanks, similarly, no plankton was applied to the TD tanks. The tanks were stocked with two to three weeks old rainbow shark larvae $(0.18$ $\pm 0.014 \mathrm{~g}$ ), obtained from a local fish farm (Rainbow Ornamentals, Jalpaiguri, India) on 18 February' 2007 and harvested on 18 May' 2007. Fish larvae were randomly assigned to culture tanks at three different stocking densities ( 0.3 fish/1, 0.5 fish/ 1 and $1.0 \mathrm{fish} / 1$ ) for each of the live food and traditional diet regimes with three replicates for each treatment:

- live food regime: fish stocked at 0.3 (LF1), 0.5 (LF2) or 1.0 fish/1 (LF3),

- traditional diet regime: fish stocked at
0.3 (TD1), 0.5 (TD2) or 1.0 fish/1 (TD3).

Live plankton was cultured in a series of plankton culture ponds where poultry manure was applied as fertilizer every 10 days at $0.26 \mathrm{~kg} / \mathrm{m}^{3}$ (dry weight), as standardized in an earlier experiment (Jha et al., 2004). For feeding the larvae in LF tanks, about 301 of plankton water from the plankton culture ponds was transferred to each tank, twice daily. This was double the amount of plankton water made available to the ornamental fish larvae for food compared to earlier experiments with koi carp (Jha et al., 2006 a; Jha et al., 2007) to ensure that fish were fed slightly in excess of satiation and eliminate the possibility that insufficient food supply may influence growth. In the traditional diet tanks, fish were fed three times a day for the same reason. The pelleted diet was mechanically crumbled before being administered during the first month; for the rest of the study, original floating pellets $(0.24 \mathrm{~cm}$ in diameter $)$ was applied. The outlet to the tanks were constructed in such a manner that water in excess of 20001 would automatically flow out. A plankton net bordered the outlet of the LF tanks so as to prevent any plankton loss with the outflowing water. Approximately 301 of excess water was discharged from the LF tanks every time during the introduction of exogenous plankton. Since most farmers in India cannot afford aeration facilities, about $10 \%$ water from the tanks was replaced with ground water every day in place of aeration. The entire experimental unit was covered by a single layer of nylon bird netting.

Water samples were collected from the tanks weekly at 9 A.M. and routine water quality parameters (temperature, $\mathrm{pH}$, alkalinity, dissolved oxygen, BOD) and the concentrations of nutrients $\left(\mathrm{NO}_{3} \mathrm{~N}, \mathrm{NO}_{2} \mathrm{~N}\right.$, $\mathrm{NH}_{4} \mathrm{~N}$ and $\mathrm{PO}_{4} \mathrm{P}$ ) were estimated according to methods as described by APHA (1998). Plankton samples were collected with plankton net made of standard bolting silk cloth (No. 21 with $77 \mathrm{mesh} / \mathrm{cm}^{2}$ ) two times 
in a week from the live food tanks immediately after plankton water was channeled to them from the plankton culture ponds. Collected plankton samples were concentrated to $20 \mathrm{ml}$ and preserved in $4 \%$ formalin. Enumerations of $1 \mathrm{ml}$ of concentrated plankton were performed under a stereoscopic microscope using Sedgwick Rafter Counting Cell. The plankton abundance and species diversity were similar in the live food tanks (table I), since they received daily plankton water from the same source. Cladocerans were in higher abundance in the environment (41.90\%) compared to copepods $(38.57 \%)$, rotifers $(12.42 \%)$ and phytoplankton $(7.11 \%)$.

The weight of the fish were recorded at the beginning and during harvest. During the process, all the fish stocked in the tanks were weighed individually to the nearest $0.001 \mathrm{~g}$. The number and percent of deformed individuals were also calculated during harvest. Dead fish were removed daily, they were not replaced during the course of study, and differences between the number of fish stocked and the number of fish at harvest were used to calculate percent mortality in each treatment. Final survival and deformities percentage were normalized using angular transformation (Mosteller and Youtz, 1961) before being subjected to further statistical analysis. The Specific Growth Rate (SGR) was calculated as:

$$
S G R=100\left[\left(\ln W_{t}-\ln W_{0}\right) / t\right] ;
$$

where:

$\mathrm{W}_{0}$ and $\mathrm{W}_{t}$ are the initial and final live weight of fish (g) respectively, and (t) is the culture period in days (Ricker, 1995).

The number of marketable fish at the end of the growth period was calculated using the function for a normal distribution curve, where $\mathrm{z}=(\mathrm{y}-\mu) / \sigma$; $\mathrm{y}$ is the least marketable weight $(4 \mathrm{~g}), \mathrm{m}$ is the mean weight of the population, $\mathrm{s}$ is the standard deviation of the total weight and $\mathrm{z}$ follows the standard normal probability distribution which determines the probability of finding fish above a given range. The number of marketable fish (n) was then determined using the table value of the normal probability distribution (p) as follows: $n=(1-p) *$ total number of viable fish produced (number of viable fish= number of fish produced - number of deformed individuals). The data on body weight, SGR, survival rate and fish deformities were compared using one-way analysis of variance (ANOVA) and Duncan's Multiple Range Test. The statistical analyses were performed using Microsoft Excel and Mstat software programmes. The differences were considered statistically significant at the probability level $\mathrm{p}<0.05$.

Table I. Species composition, average abundance (number/l) and relative abundance (\% of total numbers) of planktonic organisms present in the live food tanks. (Composición de especies, abundancia media (número/l) y abundancia relativa (\% del número total) de organismos planctónicos presentes en los tanques con alimento vivo).

\begin{tabular}{lrr}
\hline Plankton & number/l & \multicolumn{1}{c}{$\%$} \\
\hline Daphnia & 330.12 & 11.84 \\
Moina & 400.22 & 14.35 \\
Ceriodaphnia & 313.78 & 11.25 \\
Bosmina & 124.31 & 4.46 \\
Cladocera & 1168.43 & 41.90 \\
Cyclops & 475.99 & 17.07 \\
Diaptomus & 45.97 & 1.65 \\
Nauplii & 553.64 & 19.85 \\
Copepoda & 1075.60 & 38.57 \\
Brachionus & 213.77 & 7.67 \\
Keratella & 132.67 & 4.76 \\
Rotifera & 346.44 & 12.42 \\
Chlorella & 48.98 & 1.76 \\
Navicula & 70.88 & 2.54 \\
Spirogyra & 39.00 & 1.40 \\
Scenedesmus & 3.24 & 0.12 \\
Phacus & 30.78 & 1.10 \\
Synedra & 5.24 & 0.19 \\
Phytoplankton & 198.12 & 7.11 \\
Total Plankton & 2788.59 & - \\
\hline
\end{tabular}


Table II. Growth performance, survival and deformities at the end of three-month growth period (18 February' 2007-18 May' 2007) of rainbow shark reared in concrete tanks at different stocking densities. (Ritmo de crecimiento, supervivencia y deformidades de E. frenatus al final de un periodo de crecimiento de tres meses (18 febrero 2007-18 mayo 2007) en tanques de hormigón a diferentes densidades).

\begin{tabular}{lcccccc}
\hline & \multicolumn{7}{c}{ Treatment } \\
& LF1 & LF2 & LF3 & TD1 & TD2 & TD3 \\
\hline Harvest weight (g) & $7.31 \pm 0.13^{\mathrm{a}}$ & $6.73 \pm 0.10^{\mathrm{b}}$ & $4.55 \pm 0.23^{\mathrm{c}}$ & $6.72 \pm 0.11^{\mathrm{b}}$ & $3.78 \pm 0.26^{\mathrm{d}}$ & $3.16 \pm 0.13^{\mathrm{e}}$ \\
SGR (\%/day) & $4.12 \pm 0.05^{\mathrm{a}}$ & $4.03 \pm 0.03^{\mathrm{a}}$ & $3.60 \pm 0.05^{\mathrm{b}}$ & $4.03 \pm 0.02^{\mathrm{a}}$ & $3.39 \pm 0.03^{\mathrm{c}}$ & $3.19 \pm 0.02^{\mathrm{d}}$ \\
Survival rate (\%) & $97.83^{\mathrm{a}}$ & $91.10^{\mathrm{c}}$ & $84.00^{\mathrm{d}}$ & $93.17^{\mathrm{b}}$ & $77.20^{\mathrm{e}}$ & $48.05^{\mathrm{f}}$ \\
Deformed individuals (\%) & $1.67^{\mathrm{e}}$ & $4.20^{\mathrm{d}}$ & $9.25^{\mathrm{b}}$ & $4.33^{\mathrm{d}}$ & $8.10^{\mathrm{c}}$ & $12.60^{\mathrm{a}}$ \\
\hline
\end{tabular}

abcdef Different superscripts in a row indicate statistically significant differences between means at $p<0.05$.

\section{RESULTS}

Harvest weight of rainbow shark was affected by the stocking density (table II). Under any particular diet regime, maximum harvest weight was achieved in the treatments with lowest stocking densities (LF1 and TD1), compared to treatments with higher stocking densities $(\mathrm{p}<0.05)$. The specific growth rate (SGR) was quite high $(>3.0)$ in all the treatments. Stocking density similarly influenced survival rates of fish, and the LF1 (97.83\%) and TD1 (93.17\%) recorded significant higher survival rates, compared with treatments with higher densities $(p<0.05)$. Fish deformities were significantly higher in LF3 and TD3 $(\mathrm{p}<0.05)$, compared with treatments with low stocking densities. At any given stocking density, the live food treatment showed better growth and survival, compared to traditional diet treatment (table II).

To determine the output of marketable fish, the percentage and number of fish above a total weight of $4 \mathrm{~g}$ was estimated from the probability distribution at the end of the study. Although all the fish collected from the LF1, LF2, and TD1 treatments could be marketed, since they achieved the minimum marketable size, the highest number of marketable fish was produced in LF3 (table III), which had a stocking density of $1.0 \mathrm{fish} / 1$. In the traditional diet tanks, increase in stocking density resulted in production loss as very few ( $17.97 \%$ in TD2) or none $(0 \%$ in TD3) of the fish produced in these treatments could be marketed.

Table III. The average number of marketable rainbow shark (those heavier than $4.0 \mathrm{~g}$ ) produced/tank (NMFP), and expressed as a percentage of total number of fish produced* (A) and as a percentage of number of fish stocked $(B)$ in the different treatments. (Número medio de $E$. frenatus comercializables (mayores de $4 \mathrm{~g}$ ) producidos/tanque (NMFP) y expresados como porcentaje del total de peces producidos* (A) y como porcentaje del número de peces explotados en cada tratamiento (B)).

\begin{tabular}{cccccc}
\hline & \multicolumn{3}{c}{ Stocking density } & \multicolumn{4}{c}{ Marketable fish produced } \\
& L & T & NMFP & A & B \\
\hline LF1 & 0.3 & 600 & $577^{\mathrm{c}}$ & $100^{\mathrm{a}}$ & $96.17^{\mathrm{a}}$ \\
LF2 & 0.5 & 1000 & $869^{\mathrm{b}}$ & $100^{\mathrm{a}}$ & $86.90^{\mathrm{c}}$ \\
LF3 & 1.0 & 2000 & $1491^{\mathrm{a}}$ & $99.70^{\mathrm{a}}$ & $74.53^{\mathrm{d}}$ \\
TD1 & 0.3 & 600 & $533^{\mathrm{d}}$ & $100^{\mathrm{a}}$ & $88.84^{\mathrm{b}}$ \\
TD2 & 0.5 & 1000 & $124^{\mathrm{e}}$ & $17.97^{\mathrm{b}}$ & $1.24^{\mathrm{e}}$ \\
TD3 & 1.0 & 2000 & $0^{\mathrm{f}}$ & $0^{\mathrm{c}}$ & $0^{\mathrm{e}}$ \\
\hline
\end{tabular}

*excluding deformed (and injured) fish. Stocking density L: fish/l; T: fish/tank.

Different superscripts in a column represent statistically significant differences $(p<0.05)$. 
Water temperature ranged from $22^{\circ} \mathrm{C}$ to $35^{\circ} \mathrm{C}$ during the entire culture period. On any given sampling date, the temperature did not vary between the different treatments $(p>0.05)$. The results of the various water quality parameters in the experimental tanks are presented in table IV. $\mathrm{pH}$ values in all the treatments never averaged below 5.13, with a maximum average of 7.38 recorded in the LF1 treatment. There were marked differences in water quality among the treatments (table IV). Values of dissolved oxygen were highest in LF1 treatment, followed by LF2, TD1, LF3, TD2 and TD3 $(\mathrm{p}<0.05)$. The opposite was the case for free $\mathrm{CO}_{2}$ concentration, where the highest average value was recorded from TD3, followed by TD2, LF3, TD1, LF2 and LF1 $(\mathrm{p}<0.05)$. Average bicarbonate alkalinity, phosphate, nitrate, nitrite, and ammonium nitrogen were significantly higher $(\mathrm{p}<0.05)$ in TD2 and TD3, compared to other treatments (table IV).

\section{DISCUSSION}

At any given stocking density, the live food treatment appeared to be more effective compared to the traditional diet (pelleted feed) treatment. Studies on food requirements of ornamental cyprinids lay emphasis on the importance of live food. Martin (1983) reported on the supply of zooplankton to goldfish ponds by producers in the United States. Abi-Ayad and Kestemont (1994) reported an increment of growth in goldfish fed with live Artemia, compared to fish fed with dry diet. Lubzens et al. (1987) observed that goldfish and koi carp fed with rotifer, Brachionus plicatilis, in combination with artificial feed, showed better growth (and survival, in the case of koi carp) than fish fed with dry diet only. Appelbaum et al. (1986) and Van Damme et al. (1989) reported high mortality rates of koi carp larvae and juveniles when fed with artificial diets. Cyprinid larvae are known to prefer natural food items such as free-living protozoa and rotifers, and larger planktonic organisms like cladocerans and copepods at fry and fingerling stage (Jhingran and Pullin, 1985). Studies on feeding behaviour and food selection of koi carp and goldfish indicated a strong preference for cladocerans and negative selection of copepods and phytoplankton (Jha and Barat, 2005b; Jha et al., 2006b). Significantly higher growth and survival rates were observed in koi carp fry fed with exogenous plankton, compared with pelleted diet (Jha and Barat, 2005b; Jha et al., 2006a; Jha et al., 2007). In the only report available to the author on the husbandry of rainbow shark, a combination of greenwater infusoria (including mainly ciliates) with artificial diets yielded better growth, compared to fish fed with artificial feed only (McGovern-Hopkins et al., 2002). In nature, they feed on algae, periphyton, phytoplankton and some zooplankton (Rainboth, 1996).

Growth rate of fish are principally a function of the availability of preferred food and there is generally an inverse relationship between stocking density and individual size of fish produced, primarily because the food supply has to be shared between individuals (Gress et al., 1996; Sharma and Chakrabarti, 1999). In our experiment, all the fish were fed to satiation. Hence, food availability alone cannot have caused the differences in the growth rate between the different stocking densities. It is well known that carp fry respond quite rapidly to different stocking densities in their competition for space as well as food. In an earlier experiment, koi carp fed to satiation showed significantly higher growth rate when stocked at low densities, compared to higher densities (Jha and Barat, 2005a). Cage culture experiments in Israel have shown common carp to be extremely sensitive to stocking density (Feldlite and Milstein, 1999), where increased stocking density reduced the space volume available per fish. Violating behaviour requirements for space can affect growth through endocrine responses or disruption to feeding efficiency (Pankhurst 


\section{EXOGENOUS PLANKTON AS FOOD, AND REARING OF ORNAMENTAL CYPRINIDS}

and Van der Kraak, 1997; Schreck et al., 1997). Cannibalism in many species of fish appears to be directly influenced by the availability of space and shelter (Smith and Reay, 1991; Herbert et al., 2003).

Under any particular diet regimen, higher accumulation of excrements and metabolic wastes from the fish led to significantly higher concentrations of nitrogen compounds and simultaneously lowered the dissolved oxygen in the treatments with higher stocking densities, compared to lower density tanks. At any given stocking density, the live food treatment showed higher dissolved oxygen and lower nutrient levels, compared to the traditional diet treatment. Low dissolved oxygen is considered as one of the limiting factors to fish production. According to Tarzwell (1957), a minimum of $3.0 \mathrm{mg} / \mathrm{l}$ dissolved oxygen is necessary for healthy fish life. In our experiment, the dissolved oxygen levels never reached below the $3.0 \mathrm{mg} /$ 1 limit, which could be credited to a large extent to the daily exchange of water from the tanks.

Different species are differently sensitive to nitrogen toxicants. The main source of ammonia (both unionized ammonia and ammonium ion) in fish ponds is fish excretion (Hargreaves and Tucker, 2004). This explains for the significantly high ammonium ion concentration in tanks with high stocking densities. Although unionized ammonia was not estimated in our experiment, it is known to be in equilibrium with the development of ammonium ions in water (Barat and Jana, 1990). The rate at which fish excrete ammonia is directly related to the feeding rate and the protein level in the feed (Hargreaves and Tucker, 2004). Sufficient food was applied to all the tanks during the experiment. Although biochemical composition of the food was not carried out, company catalogues suggest that Tokyu pellets contain $32 \%$ crude protein. Besides, plankton are also known to contain an optimum percentage of protein, however, this protein cannot decompose and diffuse to the water when plankton are alive. In comparison, unused food in the traditional diet tanks can act as a direct source for nutrient leaching. In our experiment, at any particular stocking density, ammonium ion was significantly higher in the traditional diet tanks, compared to live food tanks. Ammonia is generally converted to toxic nitrite, which is in turn converted to non-toxic nitrate (Durborow et al., 1997). Nitrite problems are more likely in closed intensive culture systems due to insufficient or malfunctioning filtration systems (Durborow et al., 1997). In our experiment,

Table IV. Mean \pm SE of selected water quality parameters analyzed for the six treatments at weekly intervals during the 3 month growth period. (Media \pm SE de parámetros seleccionados de la calidad del agua, analizados para los seis tratamientos a intervalos semanales durante los tres meses del periodo de crecimiento).

\begin{tabular}{|c|c|c|c|c|c|c|}
\hline & LF1 & LF2 & LF3 & TD1 & TD2 & TD3 \\
\hline $\mathrm{pH}$ & $7.38 \pm 0.14^{\mathrm{a}}$ & $7.05 \pm 0.12^{b}$ & $6.95 \pm 0.10^{b}$ & $6.86 \pm 0.14^{b}$ & $6.12 \pm 0.09^{c}$ & $5.13 \pm 0.24^{d}$ \\
\hline Dissolved $\mathrm{O}_{2}{ }^{1}$ & $6.80 \pm 0.19^{a}$ & $5.95 \pm 0.22^{b}$ & $5.19 \pm 0.20^{d}$ & $5.50 \pm 0.33^{c}$ & $4.91 \pm 0.21^{\mathrm{e}}$ & $4.22 \pm 0.36^{\mathrm{a}}$ \\
\hline Free $\mathrm{CO}_{2}^{1}$ & $4.16 \pm 0.18^{f}$ & $4.72 \pm 0.23^{e}$ & $5.66 \pm 0.09^{c}$ & $5.10 \pm 0.29^{d}$ & $6.33 \pm 0.24^{b}$ & $7.78 \pm 0.41^{\mathrm{a}}$ \\
\hline Total alkalinity ${ }^{1}$ & ${ }^{1} 20.05 \pm 0.81^{\mathrm{e}}$ & $28.30 \pm 1.20^{d}$ & $36.72 \pm 2.06^{c}$ & $35.05 \pm 1.84^{c}$ & $46.11 \pm 2.24^{b}$ & $56.30 \pm 3.41^{\mathrm{a}}$ \\
\hline $\mathrm{NO}_{3} \mathrm{~N}^{1}$ & $0.071 \pm 0.008^{a}$ & $0.105 \pm 0.012^{\mathrm{e}}$ & $0.220 \pm 0.031^{c}$ & $0.132 \pm 0.016^{d}$ & $0.259 \pm 0.021^{b}$ & $0.381 \pm 0.031^{\mathrm{a}}$ \\
\hline $\mathrm{NO}_{2} \mathrm{~N}^{1}$ & $0.016 \pm 0.004^{d}$ & $0.021 \pm 0.003^{\mathrm{d}}$ & $0.028 \pm 0.002^{c}$ & $0.025 \pm 0.002^{c}$ & $0.036 \pm 0.004^{b}$ & $0.071 \pm 0.010^{\mathrm{a}}$ \\
\hline $\mathrm{NH}_{4} \mathrm{~N}^{1}$ & $0.126 \pm 0.021^{\mathrm{a}}$ & $0.185 \pm 0.031^{\mathrm{e}}$ & $0.267 \pm 0.024^{c}$ & $0.210 \pm 0.014^{d}$ & $0.406 \pm 0.041^{b}$ & $0.612 \pm 0.054^{a}$ \\
\hline $\mathrm{PO}_{4} \mathrm{P}^{1}$ & $0.130 \pm 0.012^{\mathrm{e}}$ & $0.172 \pm 0.017^{d}$ & $0.224 \pm 0.016^{c}$ & $0.223 \pm 0.028^{c}$ & $0.351 \pm 0.022^{b}$ & $0.480 \pm 0.045^{a}$ \\
\hline
\end{tabular}

${ }^{1} \mathrm{mg} / \mathrm{l}$; ${ }^{\text {abdeffData }}$ in the same row with different superscripts are significantly different $(p<0.05)$. 
daily exchange of water from the tanks ensured that nitrite problems were not much pronounced, however, significantly higher concentrations of nitrite was estimated from TD3 and TD2, compared to other treatments.

Significantly higher $(\mathrm{p}<0.05)$ incidence of fish deformities (mostly bent fins) was obtained in the treatments with higher stocking densities. Besides, several fish were injured or wounded in the TD3 and LF3 tanks and had to be culled. They were also counted in the deformed fish category. This could be attributed to the behaviour of rainbow shark. According to a preliminary species report by Sandford (1998), rainbow shark can be aggressive towards each other sometimes ripping each other's fins to shreads. This could also be influenced by the availability of space and shelter, as described earlier. At any particular stocking density, higher incidence of deformities in the traditional diet tanks, compared with the live food tanks could be due to nutritional deficiencies caused by lower abundance of plankton and possible leaching of nutrients out of the pelleted food. Goldblatt et al. (1979) demonstrated that pelleted diets exhibit a remarkable loss of vital nutrients, such as vitamins and amino acids, within a short period of exposure to water.

Both feeding regime and stocking density had an effect on the number of marketable fish. In contrast to food fish production, where the total number of fish produced determines productivity (Jolly and Clonts, 1993), ornamental fishes are sold as individuals and can only be sold once they have reached a particular size $(4 \mathrm{~g})$, provided, there are no deformities or injuries. The livefood tanks appeared to be highly productive, compared to the traditional diet tanks. The results from the probability distribution

\section{BIBLIOGRAPHY}

Abi-Ayad, A. and Kestemont, P. 1994. Comparison of nutritional status of goldfish (Carassius auratus) larvae fed with live, mixed or dry diet. table (table II) indicate that stocking rainbow shark at a density of 1.0 fish/ 1 yielded the highest number of saleable fish from a tank volume of 20001, when fed with live plankton. While the results consistently showed that increasing density reduced growth (table I), it would appear logical to reduce the stocking density, so that a faster growth rate is allowed, and the fish can quickly reach the smallest marketable size ( 4 g). However, no significant increase in price for rainbow shark that grow larger than the minimum marketable size $(4 \mathrm{~g})$ in the wholesale market in India provide strong financial incentives for farmers to maintain fishes at the smallest marketable size. The goal of production is to produce the highest number of fish of the given size ( $4 \mathrm{~g})$ with consistently low size variation. Hence, although the weight gain of rainbow shark was considerably higher in LF1 and LF2 treatments (table I), LF3 (1.0 fish/l) seemed to be the optimal density for stocking rainbow shark, since, the number of marketable fish was highest in that treatment.

From the present experiment, it appears that introduction of exogenous plankton as food allows for increased stocking density for intensive rearing of rainbow shark. Further research on husbandry management of rainbow shark needs to be conducted.

\section{ACKNOWLEDGMENTS}

The author is grateful to Dr. S. Barat, Reader, Department of Zoology, University of North Bengal (NBU), for his constant encouragement. The Head of Department of Zoology, NBU, is acknowledged for providing laboratory facilities. Mr. Kripan Sarkar, owner of the Rainbow Ornamental Fish Farm, Jalpaiguri, India, provided the fish and experimental support.

Aquaculture, 128: 163-176.

APHA. 1998. Standard methods for the examination of water and wastewater, $20^{\text {th }}$ Edition. American 


\section{EXOGENOUS PLANKTON AS FOOD, AND REARING OF ORNAMENTAL CYPRINIDS}

Public Health Association, American Water Works Association and Water Pollution Control Federation. Washington.

Appelbaum, S., Anderson, P. and Mochendorf, C. 1986. Cannibalism in reared koi carp larvae. In: R. Billard and J. Marcel (Eds.). Aquaculture of Cyprinids. INRA. Paris. pp. 235-239.

Asano, L., Ako, H., Shimizu, E. and Tamaru, C.S. 2003. Limited water exchange production systems for freshwater ornamental fish. Aquacult. Res., 34: 937-941.

Barat, S. and Jana, B.B. 1990. Density differences of heterotrophic bacteria of water between carnivorous catfish farming and polyculture system of herbivorous carps. In: G.K. Manna and B.B. Jana (Eds.). Impacts of Environment on Animals and Aquaculture. University of Kalyani. Kalyani. pp. 207-214.

Cole, B., Tamaru, C.S. and Bailey, R. 1997. A manual for commercial production of the gourami, Trichogaster trichopterus, a temporary paired spawner. CTSA Publication Number 135. Center for Tropical and Subtropical Aquaculture. Waimanalo. Hawaii.

Degani, G. 1993. Growth and body composition of juveniles of Pterophyllum scalare (Liechtenstein) (Pisces: Cichlidae) at different densities and diets. Aquacult. Fish. Manage., 24: 725-730.

Durborow, R.M., Crosby, D.M. and Brunson, M.W. 1997. Nitrite in fish ponds. SRAC Publication $n^{\circ}$ 462, Southern Regional Aquaculture Center. Mississippi State University. Stoneville.

Feldlite, M. and Milstein, A. 1999. Effect of density on survival and growth of cyprinid fish fry. Aquacult. Int., 76: 399-411.

Fernando, A.A. and Phang, V.P.E. 1985. Culture of the guppy, Poecilia reticulata in Singapore. Aquaculture, 51: 49-63.

Goldblatt, M.J., Conklin, D.E. and Brown, W.D. 1979. Nutrient leaching from pelleted rations. In: J.E. Halver and K. Tiews (Eds.). Finfish Nutrition and Fish Feed Technology (Vol. 2). Heenemann. Berlin. pp. 117-129.

Gress, P., Lim, P. and Belaud, A. 1996. Effect of initial stocking density of larval pikes Esox lucius L. 1758 on survival, growth and daily food consumption (zooplankton, chaoboridae) in intensive culture. Bull. Piscicult. Francaise, 343: 153-174.

Hargreaves, J.A. and Tucker, C.S. 2004. Managing ammonia in fish ponds. SRAC Publication $n^{\circ}$ 4603, Southern Regional Aquaculture Centre. Mississippi State University. Stoneville.

Herbert, B.W., Graham, P.A. and Foster, S.D. 2003. Effects of added shelter and stocking density on growth of sleepy cod Oxyeleotris lineolatus in ponds. J. World Aquacult. Soc., 34: 433-440.

Jha, P. and Barat, S. 2005a. The effect of stocking density on growth, survival rate, and number of marketable fish produced of koi carps, Cyprinus carpio vr. koi, in concrete tanks. J. Appl. Aquacult., 17: 89-102.

Jha, P. and Barat. S. 2005b. Management induced changes in food selection, growth and survival of koi carp, Cyprinus carpio var. koi L., in tropical ponds. Isr. J. Aquacult., 57: 115-124.

Jha, P. and Barat, S. 2005c. Effect of water exchange on water quality and the production of ornamental carp (Cyprinus carpio var. koi L.) in concrete tanks manured with poultry excreta. Arch. Pol. Fish., 13: 77-90.

Jha, P., Sarkar, K. and Barat, S. 2004. Effect of different application rates of cowdung and poultry excreta on water quality and growth of ornamental carp, Cyprinus carpio vr. koi, in concrete tanks. Turk. J. Fish. Aquat. Sci., 4: 1722.

Jha, P., Barat, S. and Nayak, C.R. 2006a. A comparison of growth, survival rate and number of marketable koi carp produced under different management regimes in earthen ponds and concrete tanks. Aquacult. Int., 14: 615-626.

Jha, P., Sarkar, K. and Barat, S. 2006b. Comparison of food selection and growth performance of koi carp, Cyprinus carpio L., and goldfish, Carassius auratus (L.) in mono- and polyculture rearing in tropical ponds. Aquacult. Res., 37: 389-397.

Jha, P., Barat, S. and Sarkar, K. 2007. Comparative effect of live-food and manured treatments on water quality and production of ornamental carp, Cyprinus carpio var. koi L., during winter, summer, monsoon and post monsoon growout experiments in concrete tanks. J. Appl. Ichthyol., 23: 87-92.

Jhingran, V.G. and Pullin, R.S.V. 1985. A hatchery manual for the common, Chinese and Indian major carps. ICLARM Stud. Rev., 11: 1-191.

Jolly, C.M. and Clonts, H.A. 1993. Economics of 
Aquaculture. The Haworth Press. Binghamton. New York.

Kaiser, H., Britz, P., Endemann, F., Haschick, R., Jones, C.L.W., Koranteng, B., Kruger, D.P., Lockyear, J.F., Oellermann, L.K., Olivier, A.P., Rouhani, Q. and Hecht, T. 1997. Development of technology for ornamental fish aquaculture in South Africa. S. Afr. J. Sci., 93: 351-354.

Kaiser, H., Paulet, T.G. and Endemann, F. 1998. Water quality fluctuations in a closed recirculating system for the intensive culture of the guppy, Poecilia reticulata (Peters). Aquacult. Res., 29: 611-615.

Lubzens, E.S., Rothbard, S., Blumenthal, A., Kolodny, G., Perry, B., Olund, B., Wax, Y. and Farbstein, H. 1987. Possible use of Brachionus plicatilis (O.F. Muller) as food for freshwater cyprinid larvae. Aquaculture, 60: 143-155.

Martin, M. 1983. Goldfish farming. Part III. Aquacult. Magazine, 9: 30-34.

McGovern-Hopkins, K., Iwai, G. and Tamaru, C.S. 2002. Can an artificial feed be used to raise rainbow shark, Epalzeorhynchos erythrurus larvae? Fishes of Hawaii, Honolulu Aquarium Society, February: 1-3.

Mosteller, F. and Youtz, C. 1961. Tables of the Freeman-Tukey transformations for the binomial and poisson distributions. Biometrika, 48: 433440.

Olivier, A. and Kaiser, H. 1997. A comparison of growth, survival rate, and number of marketable fish produced of swordtails, Xiphophorus helleri Heckel (Family Poeciliidae), between two types of culture systems. Aquacult. Res., 28: 215-221.

Pankhurst, N.W. and Van der Kraak, G. 1997. Effects of stress on reproduction and growth of fish. In: G.K. Iwama, A.D. Pickering, J.P. Sumpter and C.B. Schreck (Eds.). Fish Stress and Health in Aquaculture. Cambridge University Press. Cambridge. pp. 73-93.

Pillay, T.V.R. 1993. Aquaculture. Principles and practices. Fishing News Books, Blackwell Scientific Publications Ltd. Oxford.

Rainboth, W.J. 1996. Fishes of the Cambodian Mekong. FAO Species Identification Guide for Fishery Purposes. FAO. Rome.

Ricker, W.E. 1975. Computation and interpretation of biological statistics of fish populations. Bull. Fish. Res. Bd. Can., 191: 1-382.

Sandford, G. 1998. An illustrated encyclopedia of aquarium fish. Quantum Books. London.

Schreck, C.B., Olla, B.L. and Davis, M.W. 1997. Behavioral responses to stress. In: G.K. Iwama, A.D. Pickering, J.P. Sumpter and C.B. Schreck (Eds.). Fish Stress and Health in Aquaculture. Cambridge University Press. Cambridge. pp. 145-170.

Sharma, J.G. and Chakrabarti, R. 1999. Larval rearing of common carp Cyprinus carpio: a comparison between natural and artificial diets under three stocking densities. J. World Aquacult. Soc., 30: 490-495.

Smith, C. and Reay, P. 1991. Cannibalism in teleost fishes. Rev. Fish Biol. Fish. Sci., 1: 41-64.

Tarzwell, C. 1957. Water quality criterin for aquatic life. In: Biological Problems in Water Pollution. Department of Health, Education and Welfare, P.H.S. Washington. pp. 246-272.

Van Damme, P., Appelbaum, S. and Hecht, T. 1989. Sibling cannibalism of koi carp Cyprinus carpio L. larvae and juveniles reared under controlled conditions. J. Fish Biol., 34: 855-863.

Archivos de zootecnia vol. 59, núm. 225, p. 20. 